\title{
INNOVATIONS OF ARCHITECTURAL STUDIES AT KAUNAS UNIVERSITY OF TECHNOLOGY
}

\author{
J. Kamičaitytè-Virbašienè; T. Lim; K. Zaleckis \\ Department of Architecture and Urbanism \\ Kaunas University of Technology \\ jurate.kamicaityte@ktu.It
}

\begin{abstract}
During the last decade in the context of the desired results of architectural studies described in European directive 2013/55/EU the following problems and challenges in the field of learning quality at KTU could be observed: the lack of study process flexibility; the lack of students' ability to integrate knowledge gained from different study subjects; the lack of analytical and communication skills, etc. Having in mind three basic elements, like systematicity, integrity, and flexibility, we are gradually improving architectural studies by trying to integrate related study subjects and put stronger emphasis on architectural design and urban planning study modules; to develop study results which are directly related with the precise skills necessary for architect; to seek for the new study methods, etc. We also state that even small improvements of the study methods can lead to the efficient solution of these problems. Our solutions are unusual and innovative in the context of East European traditional learning of architecture. The aim of the paper is to review the experience of solving the mentioned problems in KTU by improving study aims, results, methods, and curriculum of the first cycle study program.
\end{abstract}

Key words: architectural studies, Kaunas University of Technology, innovations 


\section{INTRODUCTION}

Architecture studies' tradition in Kaunas city in Lithuania reaches 20th c. Architecture department as separate unit was mentioned for the first time by approved Lithuanian University's Statute on 24th of March, 1922. Architecture studies in Kaunas took place both during interwar period and post-war years up to 1971. In the year 1971 Architecture studies were transferred to Vilnius Engineering Construction Institute located in Vilnius.

Department of Architecture and Urbanism (till 2013 - Department of Architecture and Land Management) is associated with renewal of architecture studies in Kaunas. After reinstatement of Independence of the country, Kaunas University of Technology in cooperation with architecture and territorial planning specialists working at Vilnius Engineering Construction Institute undertook initiative to restore training of architects in Kaunas. In 1993 University organized Science group for the aim to restore specialty of architect. In the same year following order of a tender Civil Engineering faculty admitted first group of architecture specialty containing 20 students. On 23rd of June 1995, Department of Architecture was restored. In respect of complex architecture and land management studies started by department it soon was renamed to the Department of Architecture and Land Management. In 1997 Department started pursing architecture second study cycle. In process of reorganisation of Civil Engineering and Architecture Faculty, rejection of Land Management study program and respecting prepared specialists' wide study spectrum covering both volumetric architecture and architectural questions of a landscape in 2014 division was renamed to Department of Architecture and Urbanism.

Currently Department of Architecture and Urbanism of Kaunas University of technology prepares wide profile architects having not only artistic abilities, but also highly understanding means used by the architect - constructions, engineering infrastructure, building materials, urban context, etc. KTU graduates by using acquired abilities and knowledge can successfully work in companies engaged in both architecture and urban planning or territorial planning. Department has a slogan - contextual design of any objects for the aim to improve quality and enhance coherence of living and resting environment. Currently the department pursues three study programs for preparation of architecture bachelors, architecture masters and heritage protection bachelors. Since the year 2011 department pursues art critique PhD studies. First and second cycle art study programs, first and third cycle of humanities study programs and all three study cycles of technology programs in presence aside each other create added value of architecture studies, form non-formal training atmosphere and stimulate interdisciplinary understanding of architecture.

Since the year 1997 bachelors are prepared after integrated complex study program starting from architectural design of the buildings up to territorial planning. Its unique features if comparing to the other schools of architecture in Lithuania are the following: balance of artistic and technological disciplines in architectural education; cozy atmosphere of the studies and close contacts between the students and teachers; integration of both academic knowledge and practical skills; close integration of research and education. 
More than 20 years of independence in Lithuania brought a lot of radical and abrupt changes to society. The sphere of higher education is not an exception. 11 points of European directive 2013/55/EU describe the desired results of architectural studies. During the last decade in the context of the above mentioned results the following problems and challenges in the field of learning quality and teaching methods could be observed: the lack of study process flexibility for deepening of the precise skills necessary for architect; the lack of students ability to integrate knowledge gained from different study subjects (for ex.: drawing, composition and architectural design, landscape architecture and urban planning, etc.), the lack of motivation of students at the beginning of the studies; individualism and lack of team work skills; lack of analytical and communication skills and abilities to evaluate real situation; necessity to develop spatial thinking and artistic skills permanently; lack of professional responsibility and misunderstanding of the architect's role in society, and etc. The above mentioned and other problems (for ex.: specificity of the program profile, the small number of elective courses, little freedom for students creativity, program didactic concept, etc.) were also enumerated by international group of architecture experts which visited KTU in November 2014.

While developing a systematic approach, architectural studies at Kaunas University of technology are characterized by integrity of: building design and urban planning, academic knowledge and practical skills, scientific research and design decisions, art and technology subjects. Study process, study subjects, assignments for students, and etc. are understood as the elements of one system. In this way, having in mind three basic elements, like systematicity, integrity, and flexibility, we are gradually improving our study curriculum by trying to integrate related study subjects and put stronger emphasis on architectural design and urban planning study modules; to develop study results which are directly related with the precise skills necessary for architect; to seek for the new study methods of architectural design and urban planning, etc. We also state that even small changes can have significant consequences for the whole system, i.e. even small improvements of the study methods can lead to the efficient solution of these problems. Our solutions are unusual and innovative in the context of East European traditional learning of architecture.

The aim of the paper is to review the experience of solving the mentioned problems in Kaunas University of Technology by improving study aims, results, methods, and curriculum of the first cycle study program.

\section{STUDY AIMS AND LEARNING OUTCOMES}

Study aims and outcomes of KTU Architecture bachelor study program are based on the following:

- Mission of Kaunas University of Technology refers to qualitative higher education, scientific, cultural and educational performance providing assumptions for satisfaction of economic and cultural needs of the country under swift development and increased competition conditions; create information society and reach international recognition of intellectual potential of the country. Kaunas University of Technology has strategic goal to prepare high qualification specialists, extend scientific competence and satisfy economic needs of the country for creating new products and technologies by means of implementing innovations. First cycle Architecture study program is 
intended for training not only professional skills, but also general erudition. Such purpose of a study program is closely relating to KTU mission and its strategic plan.

- Resolution № 657 of the Government of the Republic of Lithuania "On endorsement of means for implementing architecture policy trends in 20062010" adopted on 3rd of July, 2006 (Dèl LR architektūros politikos ... 2006), states necessity "To transfer European Parliament and Council Directive 2005/36/EB dated 7th of September, 2005, regarding recognition of professional qualifications to national Law".

- Chapters of European Parliament and Council Directive 2013/55/EU dated 20th of November, 2013, pointing out, what architect shall be able to do (Directive 2013/55/EU... 2013).

- Study cycles' description adopted by resolution № V-2212 of the Minister of Education and Science dated $21^{\text {st }}$ of November, 2011 (Dèl studiju pakopu aprašo... 2011).

- Recommendations of UNESCO World Heritage Committee and international conventions for training environmental quality specialists and stimulating integrated environmental management (http://whc.unesco.org/en/guidelines/).

- General requirements applicable to study programs of the Republic of Lithuania, adopted by resolution № V-501 of the Minister of Education and Science of the Republic of Lithuania (Dèl laipsni suteikiančių... 2010).

- Law on territorial planning, Law on protection of immovable cultural heritage and other laws of the Republic of Lithuania (LR teritoriju planavimo... 2013, LR nekilnojamojo ... 2004, LR saugomy teritoriju ... 2001).

- Section 42 of the Law on recognition of professional qualifications regulated by the Republic of Lithuania (Training of architects), description of the order applicable to certification of Architects, suspension of certificates and their cancellation adopted by resolution № D1-341 of Minister of Environment on 11th of July, 2005 (Dèl architektų atestavimo... 2005).

- Programs and experience of foreign universities and members of European Association for Architectural Education (EAAE) acquired in process of training architecture specialists.

- Proposals of scientific and educational staff of KTU Civil Engineering and Architecture Faculty and requests of the students;

- Opinion of employers and social partners.

Architecture studies are pursued by 4 Lithuanian schools: KTU, VGTU, VDA and $\mathrm{KU}$. Study programs pursued by Vilnius Academy of Arts and Kaunas Institute of Art are oriented to training architect-artist. Klaipeda University trains landscape architecture specialists. Vilnius Gediminas Technical University trains architects understanding artistic and engineering essentials of architecture. KTU bachelor's studies strive for training architects having humanitarian, artistic, sociological, ecological knowledge as well as knowledge of building technology, building technique, environmental protection and land management, able to prepare projects of buildings, their groups and urban complexes, and the right to enter second cycle studies. Graduates, who finished KTU architecture studies, are able to work in companies engaged in architectural design of buildings having residential, public and industrial purpose as well as their complexes; organizations of territorial planning, buildings' interior design companies, organizations designing landscapes or create new architectural design business. Exclusive feature of KTU architecture school is interaction of humanitarian, technological and art studies "under same roof", versatility of acquired architectural qualification providing possibility of more efficient adaptation to the 
labor market and realization of sustainable development principles based on artistic and technological solutions.

Though today according our experience of teaching architecture and the opinion of international group of architecture experts our first cycle study program lacks identity and should be developed to become more recognisable at the international market and to attract more students from abroad, the program learning outcomes have to be redesigned to become assessable and to reflect the specificity of the program, and etc.

Following the experts' recommendations architecture bachelor program is being rearranged to provide diverse study modules through which architecture, as a discipline involving the design, research and technology on built environments, can be explored in experimental ways. Specifying the pedagogical direction, the programme at its core operates as an Integrated Studio system. On a strategic level, the system aims to challenge the conventional understanding of design as a means of communication and to initiate creative approaches to communication as a technological means of design. On a tactical level, to incorporate varied informational manoeuvres into the process of producing, distributing and consuming spaces, the approaches are accompanied by critical inquires on the existent typologies through related historical, cultural, theoretical and philosophical examinations, and by rigorous tests on aesthetic prototyping through structural, material, mechanical and environmental investigations. This Studio-based integration of study modules encourages individual students to broaden and deepen their experience of architecture in a way of rediscovering the self, thus to develop distinct characters in the course of becoming architects. The programme delivers the innovative and practical aspects in an interdisciplinary network, in effective coordination with other Departments, in order to formulate answers to the fast advancing global demands on both academic and professional dimensions. The program aims at balancing experimental and contextual design, architectural and urban design, theoretical and historical framework, building technology and sustainability, developing students' communication and representation skills, etc.

Study results (learning outcomes) are developed in order to relate them with the precise skills necessary for architect paying the main attention to the development of students' ability to create architectural and urban planning projects satisfying aesthetic, technical, ecological, economic, ergonomic, cultural, and social criteria, and to design considering contemporary architectural trends and necessity to protect and enhance place identity, integrating eco-technological solutions; to the development of students' creativity, analytical skills, representation and communication skills, etc. They cover four different fields: architectural design and urban planning (design-based, research-based, practicebased and test-based study), theoretical and historical framework (researchbased and design-based study), building technology and sustainability (researchbased, design-based and test-based study), representation and communication (design-based and test-based study), and social and personal skills (designbased, test-based and practice-based study).

\section{STUDY METHODS AND CURRICULUM}

While developing a systematic approach, architectural studies at Kaunas University of technology are characterized by integrity of: building design and 
urban planning, academic knowledge and practical skills, research and design decisions, art and technology. Study process, study subjects, assignments for students, and etc. are understood as the elements of one system. In this way, having in mind three basic elements, like systematicity, integrity, and flexibility, we are gradually improving our study curriculum by trying to integrate related study subjects and put stronger emphasis on architectural design and urban planning study modules, to seek for the new study methods of architectural design and urban planning, to strengthen students' spatial thinking and space perception from architect's and user's points of view, to increase the number of electives, etc.

Fundamentally corresponding to the general suggestions of KTU and Directive 2013/55/EU program provides coherent frameworks of learning processes and outcomes. The coherency of each framework, set in a semester, consists in the tangible interplay between Design, Research, Test and Practical study modules, with their interplay developing along semesters to convey increasing complexity of study objectives, dynamics of contents and sophistication of methods.

Architectural design and urban planning study modules are increased up to 12 ECTS credits (instead of former 6 ECTS credits). New study method called Studio method is being introduced into these study modules. This method ensures development of students' creativity, abilities of communication, presentation, argumentation, abilities of integration of knowledge from other study modules into design and urban planning solutions, abilities to ground their solutions on broad theoretical and empirical research, and enables student to choose individual and peculiar way of becoming an architect.

In order to strengthen students' spatial thinking and space perception from architect's and user's points of view, to strengthen students critical evaluative thinking and abilities of knowledge integration, a number of thematically oriented new study modules are introduced, for ex.: Literary Proposition I: typology of spaces, Literary Inquiry I: typology of occupants, Literary Argument III: History of Urban Planning, Technological investigation I: structures 1, Technological calibration I: materials 1 , etc. These study modules mainly cover the fields of theoretical and historical framework, building technology and sustainability and are research based.

The fields of representation and communication, and social and personal skills are covered mostly by electives. Here we have numerous group of study modules related with computer aided design and planning (spatial analysis and modelling) and visualisation of architectural solutions (from CAD/CAM to GIS). Electives also encompass study modules important from building technology and sustainability point of view: building physics, engineering systems of buildings, landscape architecture, cultural heritage, etc. the main aim of which is to broaden and deepen technological knowledge.

As already mentioned before, at KTU we see the participants of the study process, teaching methods, tasks, etc. as an elements of one complex system. Complexity means that even some small changes can have huge effects on the whole system. As a result of the attitude a lot of attention is given to small things: small calibrations of already known teaching methods, indirect forms of motivation, additional tasks and possibilities for self-improvement. These "small things" have huge potential for the improvement of the results of architectural 
studies during transition period when we are creating and introducing new study program identity and structure.

While sharing our experience about the "small things" we would like to point out the most important moments of the studies in our school.

Even with the limited time schedule and definite need for the architects to have a good knowledge of technological aspects of architecture, the Artistic skills are considered as basic for activation of the right brain hemisphere. Two goals of artistic drawing studio could be mentioned here: 1) development of spatial perception and feeling of the form; 2) development of the skills of artistic improvisation. Achievement of the both goals is assured by combination of two tasks: artistic drawing of the real objects with focus on the proportions, composition, volume, etc.; artistic improvisations while using different techniques of painting - those are not related directly to architecture but increase creativity and develop artistic self-confidence.

Spatial thinking is one of the key abilities of a successful architect. Requirement to make 3D Models as a part of each project is obligatory in our school. Process of production of the models by hand at the beginning of the studies allows for "feeling the volume through making it" experience. Later, production of the model helps to validate the design solutions of the students by themselves.

There is limited number of hours used for abstract architectural compositions and there are two possible ways to use this short time in architectural studies: one big task for the semester as it was done some years ago in all schools in Lithuania or many small tasks during the semester. We are in favor of the second one: it puts an accent on development of articulation skills of architectural language instead of just presentation of the results of abstract design.

Problem oriented learning is not a new thing but small calibrations can make it more effective in the studies of architecture:

- Real locations for the projects and obligatory site analysis with focus on the actualities of the context. It allows the students to get in touch with the real life situations that could not be modeled with the high precision within pure academical tasks.

- Integration of subjects of architectural design and building constructions. Results of the studies demonstrate that parallel development of the knowledge of building constructions and design skills allows for better results in both subjects.

- Integration of urban planning and final bachelor project. During the $7^{\text {th }}$ semester students prepare an urban project on a large scale. Spot for the final bachelor projects is often selected on the base of the work of the $7^{\text {th }}$ semester. Such continuity of the projects increases the motivation, responsibility and feeling of the context of the project.

- Practical tasks in theoretical courses for obtainment of theoretical knowledge through doing instead of listening. Two examples could be mentioned. The first one: subject of urban history. Besides the lectures a practical task to prepare architectural sketch of the typical cities of the selected periods is given to the students. While working in the groups students identify the "bricks of urban fabric" after analysis of a certain number of the historical cities. The analysis involves obligatory aspects: transport and engineering infrastructure, street culture and public spaces, urban generators, functional zoning, 
morphotypes, etc. While presenting the project to the colleagues students must explain urban form in the cultural context of the period: technologies, political system, social structure, etc. The final exam of the subject is based on the problem oriented questions and various information sources could be used in the auditorium. The second example: subject of Landscape architecture. Besides the theory the practical part exists there. The last one is focused on real small tasks or real situations, e.g. design of the courtyard of the faculty. It is a recreational outdoor space of the students. The last fact gives additional motivation and helps to understand relation between design solutions and needs of the users better.

Tasks outside curricula make an important addition to the curricula of studies and help to improve learning quality. The following types of the additional tasks in KTU are used regularly:

- Inner workshops. There is tradition since several years to have one workshop per semester. Students of different courses are invited. Team work is a typical form of participation. Real architectural tasks or actual themes are selected as topics for the workshops. In the last year the inner workshop with the initiative of the students was transformed into international event. Examples of the topics of the workshops: architectural concept of KTU campus; revival of Kaunas ZOO; idea for the renovation of Khashuri square in George (organized in collaboration with the Ministry of Foreign Affairs of Lithuania); recreational space of the students in campus, etc. Some of these projects are realized in real life later.

- Inner competitions organized as an addition to studio work with the help of social partners.

- Provisions of information about the competitions and encouragement to participate with part of the expenses covered by the faculty. The following events could be named: East-East, Isover competition, Archiprix, Schindler Awards, etc.

Creation of favorable conditions for learning from colleagues should be considered as very important "small thing" too. Atmosphere of positive competition, self-motivation and learning from the colleagues at KTU School of Architecture is encouraged by the following means:

- public exhibition of projects inside the university;

- exhibitions outside of the university, e.g. exhibition of paintings in the neighborhood municipality;

- public presentation and defense of the projects since the first years of studies.

No less important part of architectural studies is international student exchanges. Students go to study in Germany, Denmark, Spain, France, Poland, Portugal and other countries. The vast majority of students feedback on the experience gained from study abroad is positive. Students establish long-term contacts with fellow students abroad. This is always an incentive for the personal development and a new and unique experience, which helps the students to acquire skills relevant for the successful implementation of their decisions in a competitive international market.

Practice makes an important part of the study process of architecture. Benefits of the architectural practice in the architectural office are understood by the students easily and proper motivation is demonstrated. Presentation of the 
student works to local societies or stakeholders become an important and attractive element of the practice.

\section{CONCLUSIONS}

1. New program identity is grounded on the development of students' creativity based on technologies, theoretical and historical framework („,design through research“,,process“ versus „result": „the right to be wrong“ (for student), "discovery together" (teacher as a partner)), communication, presentation, argumentation (learning through discussions; "the right to be wrong" (for student), if it is reasoned), variety and freedom of choice (studio method, electives, variety of work results presentation options, guest lecturers, etc.).

2. Systematicity, integrity and flexibility are three basic concepts which are employed to renovate architectural studies at Kaunas University of Technology.

3. Systematicity and integrity is implemented through arranging study results and study modules according interrelated structure of architectural and urban design, theoretical and historical framework, building technology and sustainability, communication and representation, and supportive advanced technological structural level (electives).

4. Flexibility and integrity is implemented through flexible content of study modules of theoretical and historical framework and building technology and sustainability fields related with architectural and urban design field, testbased electives for the deepening of communication skills and technological knowledge; and also by integrity of: building design and urban planning, academic knowledge and practical skills, research and design decisions, art and technology.

5. Development of artistic skills and spatial thinking, problem oriented learning, tasks outside curricula, creation of favourable conditions for learning, international students and teachers exchange, knowledge and practical skills integration, and etc. are those small things that could provide the missing flexibility of the study program during transition period and enable us to solve the various problems that arise in the study process: to eliminate differences of students primary skills, to increase students' motivation to seek contextual, high quality and interesting architectural solutions, to increase professional responsibility, to develop skills to work in different cultural contexts, and so on.

\section{BIBLIOGRAPHY}

1. Dèl architektų atestavimo tvarkos aprašo patvirtinimo. $2005 \mathrm{~m}$. liepos $11 \mathrm{~d}$. LR aplinkos ministro isakymas Nr. D1-341 [online]. The Ministry of Environment of the Republic of Lithuania, 2005 [viewed 20 March 2015]. Available from: http://www3.Irs.It/pls/inter3/dokpaieska.showdoc I?p id=260207\&p tr2=2

2. Dèl laipsni suteikiančių pirmosios pakopos ir vientisuju studiju programų bendrujų reikalavimų aprašo patvirtinimo. $2010 \mathrm{~m}$. balandžio $9 \mathrm{~d}$. LR švietimo ir mokslo ministro isakymas Nr. V-501 [online]. The Ministry of Education of the Republic of Lithuania, 2010 $\begin{array}{lllll}\text { [viewed } 21 & \text { March } & \text { 2015]. Available } & \text { from: }\end{array}$ http://www3.Irs. It/pls/inter3/dokpaieska.showdoc I?p id=369937\&p tr2=2

3. Dèl Lietuvos Respublikos architektūros politikos krypčių igyvendinimo 2006-2010 metų priemonių patvirtinimo. $2006 \mathrm{~m}$. liepos 3 d. LRV nutarimas Nr. 657 [online]. The 
Government of the Republic of Lithuania, 2006 [viewed 18 March 2015]. Available from: http://www3.Irs.It/pls/inter3/dokpaieska.showdoc I?p id=279522\&p tr2=2

4. Dèl studijų pakopų aprašo patvirtinimo. $2011 \mathrm{~m}$. lapkričio $21 \mathrm{~d}$. LR švietimo ir mokslo ministro jsakymas Nr. V-2212 [online]. The Ministry of Education of the Republic of Lithuania, 2011 [viewed 20 March 2015]. Available from: http://www3.Irs. It/pls/inter3/dokpaieska.showdoc I?p id=412604\&p tr2=2

5. Directive 2013/55/EU of the European Parliament and of the council of 20 November 2013 [online]. Official Journal of the European Union, 2013 [viewed 9 March 2015]. Available from: http://www.eaeve.org/fileadmin/downloads/sop/DIR 201355 EU amended rpq.pdf

6. Lietuvos Respublikos nekilnojamojo kultūros paveldo apsaugos įstatymas. 2004. Nr. IX2452 [online]. The Seym of the Republic of Lithuania, 2004 [viewed 21 March 2015]. Available from: http://www3.Irs.It/pls/inter3/dokpaieska.showdoc l?p id=243075\&p tr2=2

7. Lietuvos Respublikos saugomu teritoriju istatymo pakeitimo jstatymas. 2001. Nr. IX-628 [online]. The Seym of the Republic of Lithuania, 2001 [viewed 21 March 2015]. Available from: http://www3.Irs.It/pls/inter3/dokpaieska.showdoc I?p id=156931\&p tr2=2

8. Lietuvos Respublikos teritoriju planavimo istatymo pakeitimo istatymas. 2013. Nr. XII-407 [online]. The Seym of the Republic of Lithuania, 2013 [viewed 21 March 2015]. Available from: http://www3.Irs.It/pls/inter3/dokpaieska. showdoc I?p id=453032\&p tr2=2 